\title{
Built Heritage Conservation and Contemporary Urban Development: The Contribution of Architectural Practice to the Challenges of Modernisation
}

\author{
Plácido González Martínez \\ College of Architecture and Urban Planning, Tongji University, Shanghai, China
}

\begin{abstract}
An insight into the shared history of built heritage and urban development along the $20^{\text {th }}$ century reveals different attempts to solve the dialectic conflict between conservation and modernisation from the discipline of architecture. This paper makes a review of the nature, aims and results of these attempts, highlighting the contributions to the discussion that originated from Italy between the 1950s and 1980s. It points to the challenges brought by the 1972 World Heritage Convention and the extent of social, economic and urban changes that have contributed to raise awareness about urban heritage in the present time. The article departs from a value-centred framework in order to describe current architectural, cultural, economic and social issues concerning the contribution of architecture and urban planning to heritage conservation in the age of globalization. This insight will delineate new conservation practices, strategies and methodologies, especially relating to the 2011 Historic Urban Landscape Recommendation and its declared goal for sustainable urban development.
\end{abstract}

KEYWORDS historic urban landscape, urban heritage and development, modern conservation theory, value-centred approach to urban heritage conservation, sustainability

\section{Introduction}

The conflict between conservation and modernisation is deeply rooted in the history of urban development. A linear interpretation of time brought by the philosophical basis of positivism (Pacho 2005), made conservation a stronghold of resistance to modernisation in the $19^{\text {th }}$ century, renewing the relationship of Western societies with their past (Berman 1981; Riegl 2007). In a situation where this past was disappearing from the urban landscape, the culture of modernity used the pre-existing city in a remorseless way, in the spheres of science, morality and art defined by Weber (Harrington 2000). Both in a visible and in a hidden dimension, modernisation took hold: Haussmann's interventions in the city of Paris offer clear examples of the extent of these two dimensions, comprising avenues and metro tunnels; street lights and sewer infrastructures. This double-sided manifestation of modernisation has determined city building ever since, implicitly leaving its 'hidden' side to the engineering disciplines, and the 'visible' side to the realm of architecture and urban planning (Fogue Herreros 2015).
As a side effect of this division and for much of the $20^{\text {th }}$ century, the architectural contribution to the heritage debate was limited to this visible realm. It developed as an erudite discussion conducted by experts clearly adhering to an orthodox, object-centred approach to heritage. Topics in this discussion included the moral implications of modernistic or academic composition, contrast and analogy, or the consequences of the irruption of the signs of modernity in historic city centres (Athens Charter 1931).

This object-centred approach characterises the history of modern heritage conservation theory, which led finally to the promulgation of the Venice Charter as an outcome of the Second International Congress of Architects and Specialists of Historic Buildings in 1964 (ICOMOS 1964). The Venice Charter epitomises the greatest advancements in this field, and its principles are still respected among heritage practitioners. But it undeniably fell short to define intervention principles that could apply to urban environments, leaving this task as an open question for the contemporary age of massive global urbanisation.

What are the principles of intervention to apply for the 
complex nature of the contemporary city? This remains being the main question of this research, which departs from the advancements in modern urban conservation theory and practice developed in Italy during the postwar period. Their main contribution, in our opinion, was to centre the debate on planning and conservation from the perspective of architecture (Cataldi et al. 2002); a strategy whose validity in the present time we will ascertain through a value-centred approach. With this aim, this paper will evaluate how the disciplinary fundaments of this 'urban science' developed in Italy between the 1950s and 1980s were insufficient to respond to the new challenges faced by the heritage city:

- Firstly, the emergence of a value-centred approach to urban heritage from the 1970s introduced a variety of stakeholders whose interests, claims and perspectives about heritage surpassed the mere architectural ones (Harrison 2009; Fredheim and Khalaf 2016).

- Secondly, the development of the landscape approach to cultural heritage in the 1980s drew attention to historic processes and socioeconomic activities, highlighting the new paradigm of sustainability (UNESCO 2002).

- Thirdly, the changes in urban economy, due to the rise of cultural and tourism industries and real estate markets during the 1990s, pointed at heritage environments as the new core areas for future urban and economic development (Bandarin and Van Oers 2012; Hutton 2004).

Especially after the 1972 World Heritage Convention, the issuing of international charters and recommendations, like the 1976 UNESCO Nairobi Recommendation and the 1987 ICOMOS Washington Charter, has aimed to embrace this whole variety of challenges (UNESCO, 1976; ICOMOS 1987). The recent incorporation of the 2011 UNESCO Historic Urban Landscape Recommendation (HUL) to this thread has aimed to provide answers to these topics (UNESCO 2011). It has done so, by inevitably recognising the complex definition of what is heritage today and distributing agency in the prevalent architectural discourse between a constellation of different stakeholders, methodologies and cultural contexts (Bandarin and Van Oers 2012).

Nevertheless, the HUL Recommendation is nowadays understood more as an empirical process than as a fixed methodology (Taylor 2016), strongly based in the architectural principles that were present in the 2005 Vienna Memorandum of UNESCO (UNESCO 2005). Our main goal will be to detect, in the framework of a new set of values, specific issues for which the architectural perspective can provide a useful contribution to address the challenges of conservation and development. This will be achieved through a review of examples at international level, highlighting cases in China. The conclusions will generate further questions about the extent and lasting influence of these initiatives, which call for a renewed political view towards the heritage city as a project concerning the role of society in its production.

\section{The Italian Precedent and the Case of Bologna}

The aesthetic dimension of the relationship between heritage and development has always been present in the urban conservation debate. The 'character and external aspect' of historic areas were already prioritised by the Athens Charter as fundamental chapters of this problem (Athens Charter 1931), and it remains at the forefront of current heritage documents (ICOMOS 1964; ICOMOS Australia 2013; ICOMOS China 2015). But the end of World War II added new factors to the open question of reconstruction in Europe. The extent of destruction resulting from this conflict motivated a change of attitude towards the historic city on the discourse of architectural modernism, especially regarding the connection with memory and human experience.

The 'core' of the city, as it was called in the 8th CIAM (International Congress of Modern Architecture) in Hoddesdon 1951, claimed for a deeper humanistic urban reconstruction following the physical and spiritual paradigm of 'dwelling', defined by Martin Heidegger in his seminal text 'Bauen, Wohnen, Denken' (Poggeler 1973). According to Heidegger, the experience of dwelling was deemed to incorporate notions of continuity, community and domesticity: a hint that led architects and urban planners to re-establish an appreciation of historic cities.

The key to overcome the gap that the war caused in the evolution of European and Asian cities appeared in modern urban theory, by which new urban development in historic environments should transcend aesthetics and composition and find deeper architectural and urban foundations (Tafuri 1980; Choay 1992). One of the main outcomes was the rise of urban morphology, which since then became a fundamental School for the interpretation of cities (Cataldi et al. 2002). But the theoretical debate that the Italian branch of this School developed between the 1950s and 1960s showed that it was not only a matter of form. Theorists and planners like Saverio Muratori and Gianfranco Canniggia also promoted the role of culture 
against technique as a means to counteract the effects of generic modern planning in the heritage city (Caniggia and Maffei 1982; Cataldi et al. 2002).

The relationship between the past and the present was also an instrumental and political one, and the first explorations towards an 'operative' history that Muratori pursued were followed by Aldo Rossi and the members of the Tendenza School (Rossi 1999). This 'operative' role meant that history was no longer a scholarly asset out of the realm of reality, but a true source for architectural and urban design instead. The Tendenza offered thus the conceptual basis for a disciplinary approach to the relationship between the existing city and new development from the point of view of architecture theory (Tafuri 1980; Rossi 1999; Migayrou 2012). This laid the foundations of what was paradoxically called 'progressive conservation', based in two major issues:

- The development of a germinal urban science, based in exclusively architectural principles that resulted from structuralist urban analysis,

- The increased consideration towards identity, attending to social inclusiveness as the main guaranty for urban heritage conservation.

The 1973 Plan for Bologna drafted by Pierluigi Cervellati appears today as the most sophisticated attempt to manage the conservation of the heritage city from this perspective (Cervellati and Scannavini 1973). Studies on architectural typologies determined the incorporation of new functions into old monumental buildings, mainly through new public and cultural facilities, an also guided the development of specific architectural responses to the challenges of housing. This and other related experiences from Italy were acknowledged as references in Europe due to their rigorous approach, and we can clearly track their principles in the 1975 Amsterdam Declaration (Council of Europe 1975). This is especially evident in how the Amsterdam Declaration called for the preservation of the 'texture' of urban areas, the integration of conservation in urban and regional planning, and the need to extend the benefits of urban renovation to all layers of society (Council of Europe 1975) (Figure 1).

The new wave of 'integrated conservation' as it was named in the Amsterdam Declaration, had nevertheless few opportunities to definitely transform European heritage cities. The main obstacles were set in the historic events that laid the foundations of globalisation. The awareness about the scarcity of resources grew exponentially after the Oil Crisis through the 1970s, and the limits of growth affected seriously urban planning. Conditions that the Amsterdam Declaration established in order to relief pressure on historic cities, like the sustained urban development of peripheral areas, were no longer possible due to major changes in urban economies and governance (Secchi 1984; Harvey 1989).

Bologna offered a good example of these difficulties. 'Progressive conservation' intensified all kind of initiatives for the functional update and the social cohesion of the city centre, but its success relied on urban development at its northern edge: the massive new 'Fiera Bologna', designed by Kenzo Tange, which followed the model of 'directional centres' developed by urban planners in Italy during the 1960s and 1970s. A bird's eye view of Bologna shows the equivalent size of Kenzo Tange's project with the medieval city centre, and explains the fact of how despite large amounts of investment, the Fiera Bologna did not succeed in complementing the role of the heritage city.

Modern urban planning's trust in permanent growth was broken when the powerhouses of development were no longer located in the West. Lacking the symbiosis with the periphery, the protection measures taken on the historic centre were ineffective, and the city also had to face the new problem of the rapid obsolescence of the urban periphery too. As Bernardo Secchi had warned in the 1980s, the conditions had already changed (Secchi 1984). The degradation of urban heritage became unavoidable, requiring new urgent responses.

\section{New Demands for the Heritage City}

The case of Bologna was an exceptional one, for the 1973 Plan had managed to defer what was already a reality in the Western world for more than a decade. The decay of historic city centres in Europe and North America had been originated by massive suburban development between the 1950s and 1960s. Amidst a context of increasing neoliberal economic globalisation, even political attempts to counteract this process were helpless: the 'Model Cities Program', passed by US President Lyndon B. Johnson in 1966, was cancelled in 1974 after a clamorous failure.

The 1975 Amsterdam Declaration, acknowledging the exemplary character of Bologna, revealed its limitations in light of the socioeconomic changes that redefined the role of culture in the eve of globalisation. The 1976 Narobi Recommendation concerning the Safeguarding and Contemporary Role of Historic Areas insisted in the same aspects as the Amsterdam Declaration, incorporating also specific calls for urban heritage authenticity; the adoption of economic measures for revitalisation; and warning against the creation of excessive profit in urban heritage 


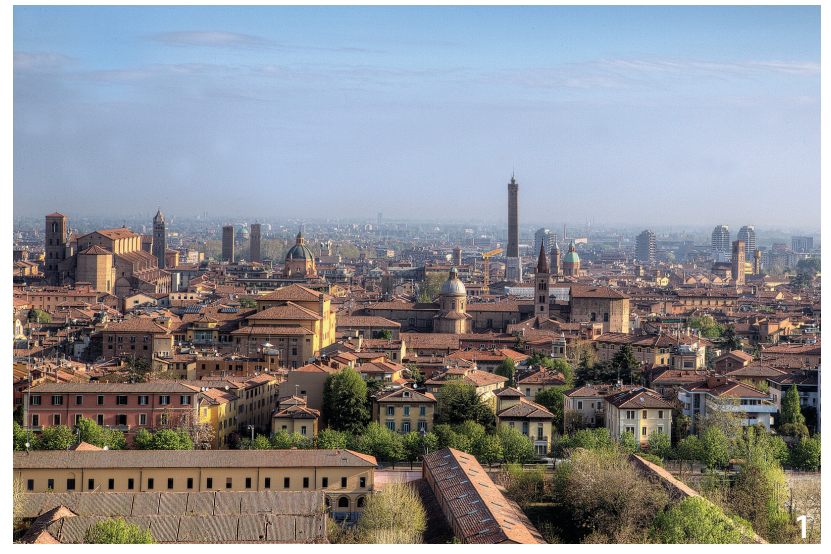

Figure 1 Bologna City Centre. (Source: Lorenzo Click, Flickr)

interventions (UNESCO 1976). We should also draw attention to the exponential increase in the number of charters and documents from the 1972 UNESCO World Heritage Convention onwards, which shows how the attempts to reach international consensus have also been unsuccessful.

A general evaluation could clearly draw a pessimistic scenario in the last 40 years, especially due to the lack of consistent policies, leading to the banalisation of the historic city (Munoz 2010). A critical review of international recommendations shows limited advancements in general, compared to the wide scope of urban challenges encompassed by the Nairobi Recommendation. Taking for instance the 1987 Washington Charter (ICOMOS 1987), the elements on which urban authenticity is based-patterns, buildings, formal appearance, territory, and functionsare insufficient to address contemporary challenges of the 'heritage city'.

This means, that once the whole urban substance has become a potential object of heritagisation, non-specific heritage menaces emerge against it, such as gentrification, climate change, mass tourism, commodification and poverty. Also the 1994 Nara Charter (UNESCO 1994), while recognising the importance of cultural diversity, falls short of giving answers to urban issues. And the efforts to bring tourists as legitimate stakeholders of urban heritage management in the 1996 San Antonio Document only addresses a minor part of the general discussion (ICOMOS 1996).

The Washington Charter expressed concerns about the integration of contemporary architecture in historic environments that have arisen in the beginning of the $21^{\text {st }}$ century, when the negative effects of development increased alarmingly. The case of Cologne, after its inscription in the World Heritage in Danger list in 2004, was a clear example of the extent of the problem. The answer from UNESCO had a clear orientation: how to conceal development and conservation required specific answers, and as the 2005 Vienna Memorandum showed, many of them still were to be found in the field of architecture (UNESCO 2005).

Even though many of the strategies developed by the 'urban science' Tendenza became obsolete, the renewed claims for architecture deserve careful attention. In our contention, there is still room for updating specific architectural discourses in urban heritage conservation, contextualized in globalisation and the influence of information technologies:

- Firstly, pointing at the potential of the landscape approach as a method suited to the history, economy and society of the heritage city,

- Secondly, insisting on the importance of value assessment as the fundament of heritage conservation,

- Thirdly, recognising the importance to incorporate the widest extent of disciplines and stakeholders to the production of heritage.

The discussion is still open, and most recent advancements have led to the drafting of the 2011 Historic Urban Landscape Recommendation (HUL) by UNESCO. Six years have passed since then, and the HUL Recommendation still lacks clear guidelines for its implementation. But in our opinion, this situation, together with the variety of cultural contexts represented in the eight cities currently working in this direction (WHITRAP 2016), constitutes an opportunity for creativity in urban heritage conservation. The following sections of the article develop a review of interventions in this direction, claiming for a renewed culture of design to manage the change and future development of heritage cities.

\section{Agency in Urban Heritage: New Stakeholders for a Value-based Approach}

The urban interpretation of structuralism developed by the Tendenza between the 1960s and 1980s drew a clear analogy with an orthodox approach to the production of heritage (Harrison 2009). Following the adaptation of Ferdinand de Saussure's work to urban science, the Tendenza described the city as a 'text', for which the integration of new 'words' or 'paragraphs' was an exclusive task of architects as legitimate 'authors' of the text (Rossi 1999). This orthodox perspective has been surpassed by contemporary advancements in political philosophy, the philosophy of nature, and media. These advancements currently advocate for a shared responsibility in both heritage production and city building process with other agents such as 
the citizens, deemed as the traditional passive 'readers' of the urban text (Harrison 2015).

Following the poststructuralist logic that overcame the mentioned orthodox approach, the contemporary 'urban' text is divided into a variety of imbricated narratives. These narratives, attending to the definition of Cultural Landscapes, would include socioeconomic activities and historic processes, on which the pre-existing and the contemporary are intertwined through architecture and urban planning. This is a major task, for compared to previous practice, the guidelines make compatible new development and conservation are no longer just 'architectural' -stylistic, morphological or typological-but require an expanded understanding of architecture instead.

We consider that the HUL Recommendation offers a valid framework for this expansion of the field of architecture, which would be based in the identification of new stakeholders and new values (ICOMOS Australia 1999). The identification of stakeholders contributing to the creation of an urban landscape includes an evaluation of their capacities to enhance their related values (Garcia et al. 2014). Following Latour's distinction (Latour 1998), we may identify:

- The so called human agents, referred by UNESCO in paragraph 25 of the Recommendation on the Historic Urban Landscape, including the citizens as real producers, political decision makers as promoters, and professionals together with the administration as managers of urban change.

- The so called non-human agents, acknowledged by UNESCO in paragraph 19 of the Recommendation, which would include the territory as the physical support of landscape, together with fauna and flora. They are deemed fundamental, for they not only complement human action, but establish effective relationships of 'kinship' and cooperation with human agents.

This classification aims to blur the categories of cultural and natural heritage that were enshrined in the 1972 World Heritage Convention. It seeks to integrate heritage conservation in a broader environmental agenda that relates to the general principle of sustainable development (Harrison 2015). These aims also require a new assessment of heritage values, which can no longer be based in an object-centred approach. Taking the Burra Charter approach as a reference (ICOMOS Australia 1999), values for urban conservation will incorporate specific architectural values, together with cultural, economic and social values.

\section{Architecture Values and the Crucial Question of Land Subdivision}

Aesthetics, morphology and typology occupied a central role in the Tendenza's 'operative history', which still can be recognised through international charters and documents up to the Vienna Memorandum (UNESCO 1976; ICOMOS 1987; UNESCO 2005). The interpretation of the city as a palimpsest legitimises the incorporation of contemporary architecture in heritage environments through the fulfilment of the prerequisites of authenticity and integrity. But this is not an easy task. These two factors, which are clearly recognised in the Vienna Memorandum (UNESCO 2005), seem to be apparently lost in the text of the HUL Recommendation (UNESCO 2011; Bandarin and Van Oers 2012).

As the Vienna Memorandum shows, the quest for authenticity applies, first, to style and composition in order to avoid historical falsification through 'pseudo historical design' (UNESCO 2005). This is a clear claim favouring the design principles of modernism, which could implicitly recognise a preference for certain architectural styles before other options. We consider that this is a critical Western centred statement about the aesthetics of historic environments that should also allow the introduction of a plurality of choices. But attention to this point should not avoid the discussion about the less evident, yet more critical aspects of morphology and typology. Both characterise the heritage city as an addition of relationships in a delicate balance, and specifically refer to an exceptionally sensitive issue for urban redevelopment: the continuation of urban lot sizes and property structure.

The global shift from planned to market economies in the last four decades show how this principle frequently clashes with the interests of real estate, urging for the adoption of architectural responses to this conflict. Two global cities like Berlin and Beijing, where the principles of the Tendenza had been applied during the 1970s and 1980s, are clear examples of this. For the case of Berlin, it was evident in the principles of 'behutsame Stadterneuerung' (respectful urban renovation) implemented during the IBA (International Building Exhibition) under the guidance of the architect Josef Paul Kleihues in historic quarters of Berlin such as Kreuzberg (Schmaling 2006). The search for principles of renovation in the typological roots of architecture also enabled for the exceptional design of Professor Wu Liangyong for the Beijing Ju'er Hutong between 1987 and 1991, adapting traditional housing models to new density requirements (Wu 1991).

The development of a new entrepreneurial mode of governance in the 1980s and 1990s brought these 


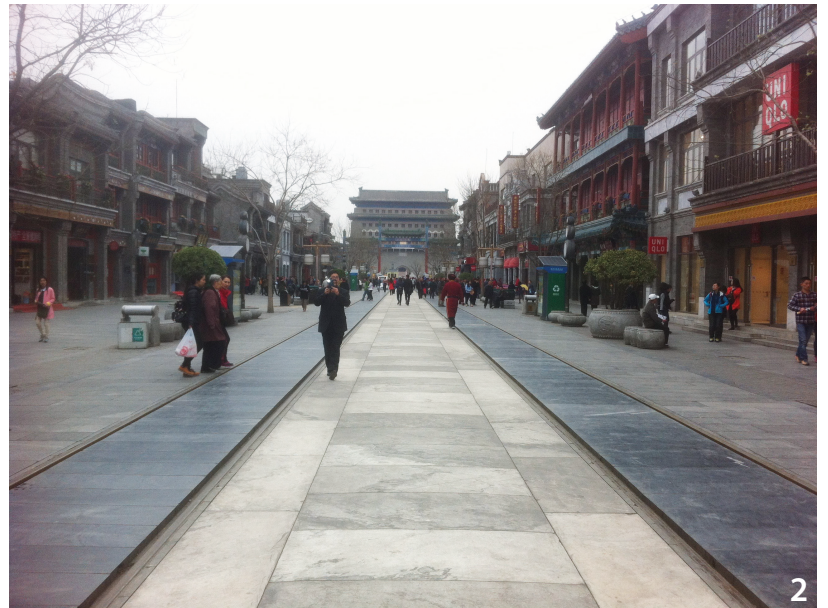

Figure 2 Qianmen Street, Beijing. (Source: the author, 2015)

successful experiences into oblivion, and for the same two cities we could mention the irreversible effects, in social and economic terms, of the aggregation of building lots in the central area in Berlin after the reunification of Germany, or the analogous demolitions process that has taken place in Beijing since the 1990s (Abramson 2007). And even though the rigorous work of architects like Aldo Rossi in the Fiedrichstadt or Zhang Yonghe in the Qianmen Gate area has aimed to provide a sense of continuity through the mastery of architectural composition, these changes in land structures have had deeper effects in the social and economic underlying tissue (Figure 2).

This is a controversial issue of policy that arises when the main revenue for municipalities is based in the real estate market (Wu 2003). And as it usually happens in deregulated economic contexts, the current reversal of this process is not resulting from the adoption of more committed policies with towards urban heritage, but as a consequence of a slower pace of economic development that progressively reduces the scale of urban interventions. The incorporation of creative city policies takes advantage of this situation, but it is a double edged sword. On the one hand, it favours the museification of public space, meaning the loss of authenticity (Ley 2003; Zukin 2010). But on the other hand, it is also leading to interesting experiences reinterpreting the aforementioned constitutive aesthetic, typological and morphological elements through the paradigm of 'micro urban regeneration' (Li 2016). For the case of Beijing, the role of the Beijing Design Week in the renovation of areas like Dashilar has been widely recognised, and projects like the Aga Khan award-winning Micro Yuan'er by Zhang Ke are a clear sample of this approach (Zhang and Zhang 2016).

\section{Cultural Values Epitomising Public Space}

A related question would be: lacking consistent policies; for how long can we take for granted the survival of this new respectful spirit? Could it also endure after the current cycle of low economic growth? Cultural values may well provide specific answers. Bologna already showed the path in this tendency in the 1960s, when programming the gradual conversion of historic buildings into libraries and museums. This tendency has been reformulated today, also incorporating public spaces and cultural corridors for urban leisure (Wansborough and Mageean 2000; Cohen 2010).

The renovation of historic environments is currently redefining the role of urban and landscape designers, aiming to recover the civic nature of public space through a new appreciation of the built environment. International references include Jan Gehl; who has been responsible for the pedestrianisation of Broadway Avenue and Times Square in New York City, as well as in other geographical and urban contexts like Copenhagen and Sao Paulo. Also the design of Wang Shu for the new Zhongshan Road in Hangzhou points to the advantages of updating traditional street layouts, continuing the accumulation of layers of history, the preservation of the social fabric and favouring the creation of pedestrian pockets as the environmental supports of neighbourhood life (Wang 2016).

The end of distinctions between cultural and natural heritage results from the acknowledgement of agency to both human and non-human actors (Garcia et al. 2014; Harrison 2015). Growing awareness to urban ecology has reinforced a territorial understanding of the city, fostering the presence of water, vegetation and fauna, as well as traditional livestock corridors (the traditional Cañadas Reales in Spain), as constitutive elements of cultural heritage. These elements were systematically 'artificialised' during urban modernisation throughout the $20^{\text {th }}$ century, and now require effective rehabilitation. A review of international cases would include the work of landscape architect Francois Helene Jourda in the margins of the river Rhone in Lyon, re-establishing the connection between the historic city centre and a five-kilometre territorial corridor. The city of Los Angeles is currently re-naturalising the artificial course of the Los Angeles River. Also the recent interventions of the Shanghai municipality in the Bund and the West Bund deserve special attention, aiming to connect major cultural infrastructures located in former industrial areas through a new landscaped 'necklace' (Figure 3).

A deeper and more provocative understanding of this issue relates to the relationship between heritage practice 


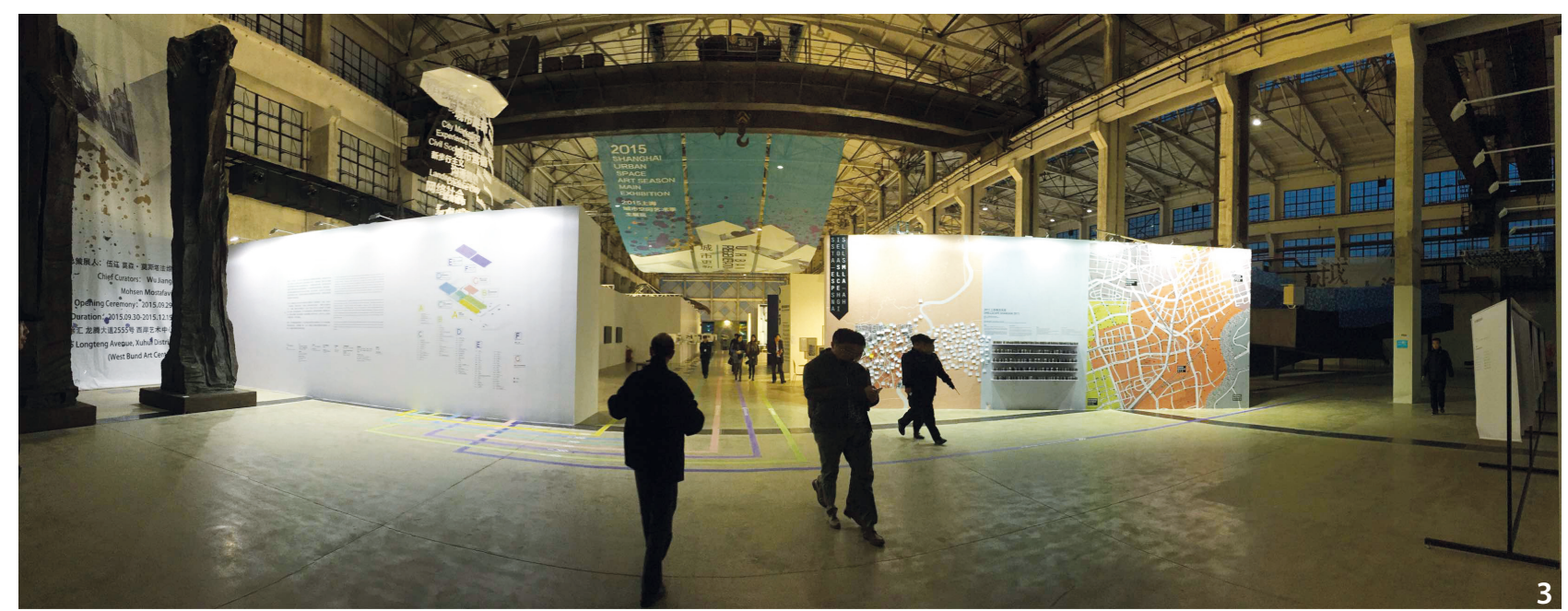

Figure 3 West Bund Art Centre. (Source: the author, 2015)

and other activities that effectively curate the environment, like ecological preservation (Harrison 2015). This applies to the recovery of autochthonous landscapes that emerged in obsolescent urban areas after the halt of productive activity (Clement 2005). This was the reason for the creation of the High Line in the west of Manhattan, now considered a reference in contemporary urban landscape interventions through the designs of Piet Oudolf, Diller Scofidio and Renfro. The example of World Heritage Sites like the Zeche Zollverein in Germany shows how this will constitute a preferential field of action for heritage and architecture practice in the coming years, especially in countries such as China, now facing a process of stark deindustrialisation.

\section{Economic Values and Productive Change}

The 'changing conditions' described by Bernardo Secchi have turned (Secchi 1984), and heritage is now deemed as a major attractor of investment in the built environment (Scott 2006; Grodach 2013). A review of the production of 'starchitects' all over the world gives evidence of the growing economic dimension of heritage conservation. Once deemed as a 'minor' part of architectural practice, important international offices such as Herzog \& De Meuron, OMA or Foster now highlight architectural and urban heritage interventions in their portfolios, and it is a fact that their contribution to urban regeneration can be measured through extra revenues in the real estate market (Fuerst et al. 2011).

The implications for architectural practice are yet more diverse. Economic values of heritage contribute to a sustainable future through low energy consumption and the development of mixed use typologies: two fundamental research fields that need to be addressed from the heritage perspective (Dalmas et al. 2015). The first of these challenges appears in terms of energy conservation, production and distribution in historic environments: the recent experience of Santiago de Compostela reveals the connection of this question to the continuity and enhancement of traditional construction systems and techniques (Ramos et al. 2003; Panero 2011). The second one aims to recover the nature of an 'operative history' of architecture, pointing not only at the value of place, but also to the legacy of architecture typologies in history that constitute valid references for the requests of contemporary mixed use economy (Abalos and Sentkiewicz 2015).

This directly relates to job creation, especially considering the influence of urban heritage for the definition of the contemporary paradigm of the creative city (Florida 2002; Florida 2008) by international institutions like UNESCO. The shift from a production economy to a creative economy is expanding like a tidal wave since Cedric Price produced his first designs for the Potteries Thinkbelt, aiming to provide new educational use to obsolete mining infrastructures in the heart of England in 1963. Recent successful experiences at an urban heritage level would include the 22@ initiative in Barcelona (Leo 2008): the renovation of the old Poblenou industrial district is not envisioned as a final product, but has been planned as a long-term process, with no fixed goals instead. This allows addressing a whole variety of layers engaged with the transition from textile to digital production, which include the provision of metropolitan and neighbourhood scale facilities, ranging from cultural to commercial uses, incorporating new employment opportunities for the local residents. 


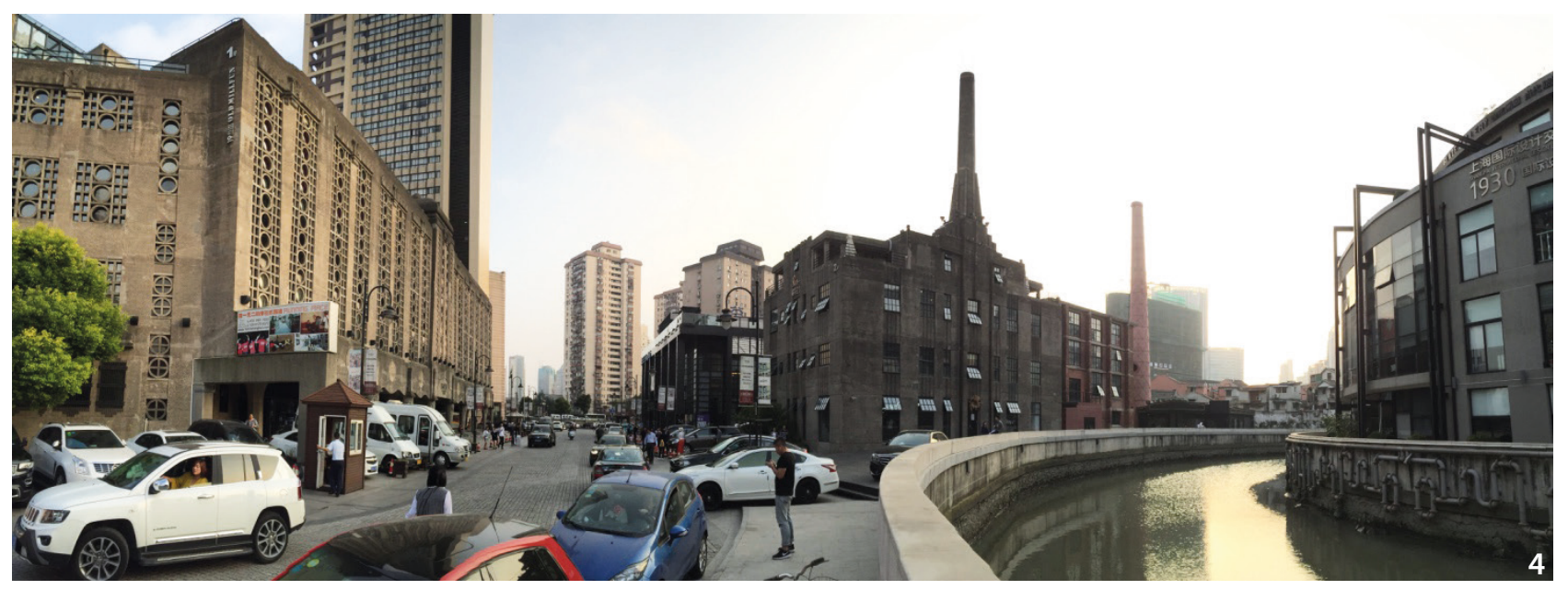

Figure 4 Shanghai Music Valley. (Source: the author, 2015)

The next urban heritage frontier in this field is located in countries like China (Keane 2009). The 798 District in Beijing has become an international reference due to its early innovativeness, despite its recent gentrification (Ren Sun 2012). Shanghai also offers clear examples of municipal and district level initiatives favouring the creation of Creative Parks, in an open competition to attract investments using the built heritage as an economic asset. Nevertheless, this also point to another direction, that of the commodification of built heritage, favouring the real estate market, as the case of Tianzifang shows (Wang 2009; Wang 2011; Zhong 2015). Other on-going initiatives, such as the Shanghai Music Valley in Hongkou district, offer some hints for a possible different path, giving special attention to the relationship between flagship interventions and the residential habitat of the lilong as a living environment. But up to date, the final results of the process remain yet to be shown (Figure 4 ).

\section{Social Values and Public Participation}

The matter of gentrification leads to the final challenge shared by conservation and development: to solve the gap between authorised heritage discourses and everyday heritage practices (Smith 2006). Urban heritage conservation must retain the inclusive character of the heritage city, prioritising the enhancement of the living conditions of the people and their contribution to the production of heritage, as well as the benefit from its outcomes. This would require evaluation of whether the shift from the traditional object-centred to the more innovative valuecentred approach has effectively contributed to perpetuate a discourse of power over heritage (Smith 2006), despite of the aims and hopes of cultural heritage documents and charters from the 1990s onwards.

These documents show general consensus on the importance of incorporating local communities in design and decision making (UNESCO 1976; COUNCIL OF EUROPE 1975; ICOMOS 1987; UNESCO 2005; UNESCO 2011), but the experience gathered in the first cities implementing the HUL Recommendation points to a fundamental handicap (WHITRAP 2016), which is the inefficient transmission of surveying and participation results to the process of planning. Novel demands from contemporary society will require creative methods of planning and design (Rannila and Loivaranta 2015), in order to adopt consistent determinations, answering the needs, aims and hopes of the population. Fortunately, the connected environment of the networked society and communication technologies enables citizen participation, and promises to abolish the differences between top-down and grassroots practices. This is the case of the Siedlung Britz in Germany, listed in the World Heritage lists, where conservation measures are based on interactive internet tools, available for use to policy makers, planners, citizens and building contractors (www.hufeisensiedlung.info).

A recent process that must not be overlooked is related to the growing transcendence of experiences led by local communities to curate public spaces, which has appeared as a frequent scenario in Western countries since the 2008 economic crisis allegedly reduced the availability of public investment in facilities and infrastructures. A myriad of urban interventions aiming to transfer agency from public authorities to grassroots initiatives has proliferated; a process that has already been acknowledged by the MoMA New York (www.uneven-growth.moma.org) as a contemporary global artistic manifestation. 


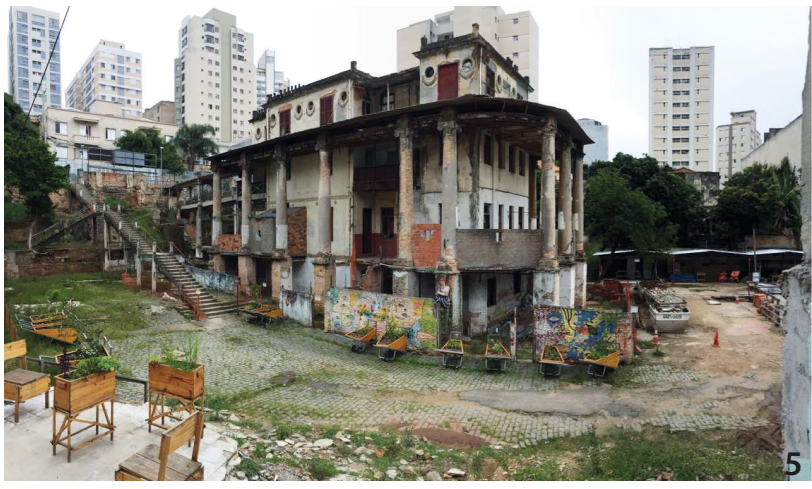

Figure 5 Vila Itororo, Sao Paulo. (Source: the author, 2016)

Following Harrison's recent explorations in the politics of heritage (Harrison 2015), these initiatives may well be included among future urban heritage intervention practices. Included in this field, the recent success of collaborative actions performed by architecture practices like EXYZT in Campo de la Cebada in Madrid, after the local government cancelled the construction of public facilities in the city centre due to lack of resources, may well show a way for the sustainable management of public spaces. This requires a new, different understanding of time and aesthetics applied to urban conservation, as the on-going renovation process of Vila Itororo in Sao Paulo (www. vilaitororo.org.br) currently shows: heritage becomes not managed, but effectively curated, in an open process that involves the former residents and that aims to establish enduring relationships between the heritage site and the surrounding environment (Figure 5).

\section{Conclusion}

Heritage has occupied a central role in the discussion about urban development from the 1972 World Heritage Convention. Different attempts have aimed to accommodate the diverging interests of conservation and change since then, with. The Tendenza offered initial valid responses to the challenges that the heritage city would face in contemporary societies, going back to the foundations of architecture; mainly typology and morphology as supporters of urban culture. But economic crisis in the West during the 1970s showed the limitations of that model due to its dependence of traditional hierarchies established since the Industrial Revolution between the city centre and the urban periphery. This was especially evident when urban obsolescence became a major issue affecting peripheral areas.

The review of heritage charters and documents originated reveals how social and cultural changes in globalised economies demand a shift from the traditional object-based approach to a theoretically more open and inclusive value-based approach (Smith 2006; Harrison 2009). These changes also affect traditional modes of urban development, offering an opportunity for the creation of alternative heritage discourses on which architectural practice still retains an important potential contribution.

In this paper we have aimed to offer an overview of current examples in this direction. The nature of the cases reveals how alternative ways of integrating urban heritage conservation and development are responding to a reorganisation of the interests around the heritage city after the 2008 economic crisis. Shrinking Western economies have completely restricted interventions by the public sector, and as result, a dual scenario has emerged. On the one hand, great urban interventions in public space and flagship cultural facilities perpetuate authorised heritage discourses, even if they comply with contemporary prerequisites of sustainability.

On the other hand, the minimal scale of grassroots urban interventions and their repercussion in specialised media, offer at the same time the illusions of proximityand with it, the possibility for immediate action by the citizenship - and an invitation to indulgent trust in their massive proliferation. Facing this situation, we should still address further questions for the future: is this plethora of grassroots action diverting attention from more unnoticed, 'hidden' interests on urban heritage, out of the focus of public evaluation? Are Authorized Heritage Discourses being challenged at all by new tools relying on participation like the Historic Urban Landscape Recommendation?

An initial evaluation would certainly cast deep shadows in this conflictive relationship between heritage conservation and urban development. In order to gain a better perspective and to reinforce the demands for equity in urban heritage, it would be necessary to bring back the definition of urban authenticity to the forefront. The HUL Recommendation has left it in a marginal position (UNESCO 2011), in what we understand as a withdrawal from a fundamental field of action for urban heritage. Especially when at the same time, authenticity has become a steadfast notion for marketing studies (Peterson 2005); authors like Zukin have advanced towards its definition from the perspective of social studies (Zukin 2010); and authors like Cohen are defining it in the field of tourism studies (Cohen 1988; Cohen 2010). This new formulation of urban heritage authenticity should provide answers to the variety of architectural, cultural, economic and social 
issues referred before, prioritising the questions of equity and justice as the major goals to achieve in the future. Because as Silverman (2015) has recently stated, heritage is ultimately a matter of spatial, cultural, economic and social rights; whose discussion can no longer be put on hold.

\section{References}

Abalos, I., and Sentkiewicz, R. 2015. Essays on Thermodynamics, Architecture and Beauty. Barcelona: Actar.

Abramson, D.B. 2007. "The Aesthetics of City-scale Preservation in Beijing." Planning Perspectives, 22: 129-166

Athens Charter for the Restoration of Historic Monuments. 1931

Bandarin, F. and Van Oers, R. 2012. The Historic Urban Landscape. Hoboken: Wiley.

Berman, M. 1981. All that is Solid Melts into Air. The Experience of Modernity. New York: Simon and Schuster.

Caniggia, G. and Maffei, G.L. 1982. Composizione architettonica e tipología edilizia. Venezia: Marsilio.

Cataldi G., Maffei G. L. and Vaccaro, P. 2002. "Saverio Muratori and the Italian School of Planning Typology." Urban Morphology 6 (1): 3-14.

Cervellati, P.L. and Scannavini, R. 1973. Bologna. Politica e Metodologia del Mestauro Mei Centri Storici. Bologna: Il Mulino.

Choay, F. 1992. Lallegorie du Patrimoine. Paris: Editions de Seuil.

Cohen, E. 1988. "Authenticity and Commoditization in Tourism." Annals of Tourism Research 15: 371-386.

Cohen, E. 2010. "Tourism, Leisure and Authenticity." Tourism Recreation Research 35 (1): 67-73.

Council of Europe. 1975. The Declaration of Amsterdam. Congress on the European Architectural Heritage. [Online] <http://www.icomos.org/en/charters-andtexts/179-articles-en-francais/ressources/chartersand-standards/169-the-declaration-of-amsterdam> [Accessed 8.30.2016]

Dalmas L., Geronimi, V., Nöel, J.F. and Tsang, T.K.S. 2015. "Economic Evaluation of Urban Heritage: an Inclusive Approach under a Sustainability Perspective." Journal of Cultural Heritage 16: 681-687.

Florida, R. 2002. The Rise of the Creative Class: And How it's Transforming Work, Leisure, Community and Everyday Life. New York: Basic Books.

Florida, R. 2008. Who's Your City? How the Creative Economy is Making Where to Live the Most Important Decision of Your Life. New York: Basic Books.

Fogue Herreros, U. 2015. Ecología Política y Economía de la Visibilidad de los Dispositivos Tecnológicos de Escala
Urbana Durante el Siglo XX. Abriendo la Caja Negra. (Ph.D. Dissertation, unpublished). Madrid: Departamento de Proyectos Arquitectónicos, ETSA Madrid.

Fredheim, L. H. and Khalaf, M. 2016. "The Significance of Values: Heritage Value Typologies Re-examined.” International Journal of Heritage Studies 22 (6): 466-481

Fuerst, F., McAllister, P. and Murray, C.B. 2011. "Designer Buildings: Estimating the Economic Value of 'Signature' Architecture." Environment and Planning A 43: $166-184$

García Vázquez, C, González Martínez, P. and Sierra Hernández, M. 2014. Producción de nueva arquitectura en la ciudad de Sevilla y su relación con el paisaje, in Fernández-Baca Casares, R. (Ed.). Guía del Paisaje Histórico Urbano de Sevilla. Sevilla: Consejería de Cultura de la Junta de Andalucía. Accessed August 30 2016. http://www.iaph.es/web/canales/patrimonio-cultural/guia_paisaje_historico_urbano_sevilla/estudios_ tematicos.html

Grodach, C. 2013. "Cultural Economy Planning in Creative Cities: Discourse and Practice." International Journal of Urban and Regional Research 37 (5): 1747-1765

Harrington, A. 2000. "Value Spheres or Validity Spheres? Weber, Habermas and Modernity." Max Weber Studies 1: 84-103.

Harrison, R. 2009. "What is Heritage?, in Harrison, R. (Ed.)." Understanding the Politics of Heritage. Manchester: Manchester University Press, 5-42.

Harrison, R. 2015. Beyond 'Natural' and 'Cultural' Heritage: Towards an Ontological Politics of Heritage in the Age of Anthropocene. Heritage and Society 8 (1): $24-42$.

Harvey, D. 1989. "From Managerialism to Entrepreneurialism: The Transformation in Urban Governance in Late Capitalism." Geografiska Annaler. Series B, Human Geography 71 (1): 3-17.

Hutton, T. 2004. "The New Economy of the Inner city." Cities 21 (2): 89-104.

Keane, M. 2009. “The Capital Complex. Beijing's new Creative Clusters, in Kong, L., O'Connor, J." Creative Economies, Creative Cities. Asian-European Perspectives. New York: Springer: 77-95.

ICOMOS (International Council on Monuments and Sites). 1964. International Charter for the Conservation and Restoration of Monuments and Sites.' Accessed August 30 2016. http://www.icomos.org/charters/venice_ e.pdf

ICOMOS. 1987. Charter for the Conservation of Historic Towns and Urban Areas (Washington Charter). 
Accessed May 3 2016. www.icomos.org/charters/ towns_e.pdf

ICOMOS Australia. 2013. The Burra Charter. Accessed August 30 2016. http://australia.icomos.org/publications/charters/

ICOMOS China. 2015. Principles for the Conservation of Heritage Sites in China. Los Angeles: The Getty Conservation Institute.

Ley, D. 2003. "Artists, Aesthetization and the Field of Gentrification." Urban Studies 40 (12): 2527-2544.

Latour, B. 1998. “To Modernize or to Ecologize? That's the Question, in Castree, N. and Willemsbraun, B. (eds.)." Remaking Reality: Nature at the Millenium. London and New York: Routledge: 221-242.

Li, Y. 2016. "Humble Opinions on Urban Micro-regeneration. Referring to Public Policy, Architectural Rethinking and Urban Authenticity." Time + Architecture 2016(4): 6-9.

Migayrou, F. 2012. La Tendenza: Architectures Italiennes 1965-1985. Paris: Centre Georges Pompidou.

Leon, N. 2008. "Attract and Connect: The 22@Barcelona Innovation District and the Internationalisation of Barcelona Business." Innovation Management, Policy \& Practice 10 (2-3): 235-246

Munoz, F. 2010. Urbanalización. Paisajes Comunes, Lugares Globales. Barcelona: Gustavo Gili.

Pacho, J. 2005. Positivismo y Darwinismo. Madrid: Ediciones Akal.

Panero, Á. 2011. Patrimonio Mundial y Modelo de Ciudad. Ciudadanos, Energía y Medio Ambiente en Santiago de Compostela. In Fernández-Baca Casares, R.; Salmerón Escobar, P.; Sanz, N. (ed.). El Paisaje Histórico Urbano en las Ciudades Patrimonio Mundial. Indicadores Para su Conservación y Gestión II. Sevilla: Consejería de Cultura de la Junta de Andalucía, pp. 227-237

Peterson, R. A. 2005. "In Search of Authenticity." Journal of Management Studies 42(5): 1083-1098

Poggeler, O. 1973. Heidegger Today, in Ballard, E.G.; Scott, C.E. Martin Heidegger: In Europe and America. The Hague: Martinus Nijhoff, 1973, 1-36.

Ramos Guallart, J., Panero Pardo, A., Camiruaga Osés, I., Tomé Ferreiro, P., Fernández Hermida, R. 2003. La oficina de Conservación y Rehabilitación de la Ciudad Histórica de Santiago, 1994-2001. Informes de la Construcción 486(55): 15-24.

Rannila, P; Loivaranta, T. 2015. "Planning as Dramaturgy. Agonistic Approaches to Spatial Enactment." International Journal of Urban and Regional Research 39(4):
788-806

Ren, X.; Sun, M. 2012. "Artistic Urbanisation: Creative industries and Creative Control in Beijing." International Journal of Urban Research, 36(3): 504-521

Rossi, A. 1999. La Arquitectura de la Ciudad. Barcelona: Gustavo Gili.

Riegl, A. 2007. El Culto Moderno a Los Monumentos. Su carácter y Sus Orígenes. Sevilla: Consejería de Cultura de la Junta de Andalucía.

Schmaling, S. 2006. "Masked Nostalgia, Chic Regression. The 'Critical' Reconstruction of Berlin." The Harvard Design Magazine 23. Accessed September 122016. http://www.harvarddesignmagazine.org/issues/23/ masked-nostalgia-chic-regression-the-critical-reconstruction-of-berlin

Secchi, B. 1984. "Le Condizioni sono Cambiate”. Casabella 498-499: 8-13.

Scott, A. 2006. "Creative Cities: Conceptual Issues and Policy Questions." Journal of Urban Affairs 28(1): 1-17

Silverman, H. 2015. Heritage and Authenticity. The Palgrave Handbook of Contemporary Heritage Research. London: Palgrave Mac Millan.

Smith, L. 2006. Uses of Heritage. London: Routledge.

Tafuri, M. 1980. Theories and History of Architecture. New York: Harper \& Row.

UNESCO (United Nations Educational, Scientific and Cultural Organization). 1976. Recommendation concerning the Safeguard and Contemporary Role of Historic Areas (Nairobi Recommendation). Accessed June 3 2016. http://portal.unesco.org/es/ev.php-URL_ $\mathrm{ID}=13133 \& \mathrm{URL} \_\mathrm{DO}=\mathrm{DO} \_$TOPIC\&URL_SECTION=201.html

UNESCO. 1994. The Nara Document on Authenticity . Accessed August 30 2016. http://whc.unesco.org/document/9379

UNESCO. 2002. World Heritage Papers 7. Cultural Landscapes: the Challenges of Conservation. Accessed January 24 2017. http://unesdoc.unesco.org/ images/0013/001329/132988e.pdf

UNESCO. 2005. Vienna Memorandum on World Heritage and Contemporary Architecture-Managing the Historic Urban Landscape. Accessed June 3 2016. http:// whc.unesco.org/uploads/activities/documents/activity-47-2.pdf

UNESCO. 2011. Recommendation on the Historic Urban Landscape. Accessed June 3 2016. http://whc.unesco. org/en/activities/638

Wang, J. 2009. "Art in Capital: Shaping Distinctiveness in a Culture-led Urban Regeneration Project in Red Town, 
Shanghai." Cities 26: 318-330

Wang, S.W.H. 2011. "Commercial Gentrification and Entrepreneurial Governance in Shanghai: A Case Study of Taikang Road Creative Cluster." Urban Policy and Research 29 (4): 363-380

Wang, S. 2016. "City Revival by Chinese Original Architecture: the Preservation and Renovation of Zhongshan Road in Hangzhou." Heritage Architecture 3: 1927.

Wansborough, M.; Mageean, A. 2000. “The Role of Urban Design in Cultural Regeneration." Journal of Urban Design 5 (2): 181-197.

WHITRAP (World Heritage Institute of Training and Research for the Asia and the Pacific Region). 2016. The HUL Guidebook. Managing Heritage in Dynamic and Constantly Changing Urban Environments. A Practical Guide to UNESCO's Recommendation on the Historic Urban Landscape. Accessed December 13 2016. http:// historicurbanlandscape.com/themes/196/userfiles/ download/2016/6/7/wirey5prpznidqx.pdf

Wu, F. 2003. "Globalisation, Place Promotion and Urban Development in Shanghai." Journal of Urban Affairs 25(1): 55-78.

Wu, L. 1991. "Rehabilitation in Beijing." Habitat International 15(3): 51-66.

Zhang, K.; Zhang, Y. 2016. "Symbiotic Renewal. 'Micro Yuan'er' by ZAO/standard architecture." Time + Architecture 2016(4): 80-87.

Zhong, S. 2015. "Artists and Shanghai's Culture-led Urban Regeneration." Cities 56: 165-171.

Zukin, S. 2010. Naked City. The Death and Life of Authentic Urban Places. New York: Oxford University Press. 